\title{
Impact of greening attitude and buyer power on supplier environmental management strategy
}

\author{
S. M. Lo
}

Received: 31 March 2014/Revised: 2 December 2014/ Accepted: 22 December 2014/Published online: 14 January 2015

(C) Islamic Azad University (IAU) 2015

\begin{abstract}
Studies on the appropriate strategies for supplier relationship management vary according to the greening approaches of a firm. The relative power of greening approaches for suppliers remains untapped. This research aims to fill this gap, arguing that firm attitudes toward going green and their dominance in supply chains affect their corresponding environmental management practices. The case study method is utilized. The main objects of study include Taiwanese firms in high-tech industries. Eleven firms were selected for in-depth investigation. Supplier management approaches are investigated from six different perspectives: supplier policy, information sharing/communication, joint action of supplier/buyer, relationship-handling issues, supplier support, and relationship quality. Results show that each case group emphasizes different perspectives. Thus, this study coined four strategies: strategic alliance, arm's length relationship, partnership, and ongoing relationship.
\end{abstract}

Keywords Green supply chain management - Buyersupplier power · Greening approach · Supplier relationship management $\cdot$ Case study

\section{Introduction}

Several organizations are considering environment-related performance when operating supply chain activities because of the increasing awareness of environmental effects (e.g., global warming and air and water pollution).

S. M. Lo $(\bowtie)$

Department of Business Administration, National Chengchi

University, Taipei, Taiwan

e-mail: Sonia.Lo@nccu.edu.tw
These companies no longer limit their concept of successful supply chain management to the maximum benefit of business, but also consider the friendliness to both the society and the environment. Thus, "Going Green" (Clarke et al. 1994) is considered an important step toward environmental sustainability (Bansal and Roth 2000; Eltayeb and Zailani 2009). Firms should not be isolated from their partners. Supplier involvement enhances the efficiency and improvement of environment-relevant performance indicators (Bowen et al. 2001; Green et al. 1998; Simpson et al. 2007).

Buyer-supplier relationship affects the implementation of green-related practices by reducing negative environmental impact (Chien and Shih 2007; Hervani et al. 2005). For example, suppliers can jointly develop green-related materials, processes, or solutions with buyer organizations to eliminate or reduce the materials used in manufacturing (Green et al. 2000). Thus, collaborating with suppliers contributes to production performance and results in positive outcomes for environment-relevant indicators (Klassen 2001; Klassen and Vachon 2003; Rao and Holt 2005; Zhu and Sarkis 2004). A group of scholars depicted an ideal environment-friendly process by integrating various greenrelated activities, such as remanufacturing (Guide et al. 2005; Guide and Van Wassenhove 2002), redesign of product/service (Hu et al. 2012), and purchasing (Green et al. 1998). Focal firms can thrive in environment-friendly supply chains by acting as a whole system (i.e., from customer to supplier ends) and can, in turn, guarantee longterm economic success (Beske and Seurig 2014; Walton et al. 1998).

Various attitudes of firms toward going green have been explored to examine how organizations can dedicate themselves to green activities (Kopicki et al. 1993; Walley and Whitehead 1994; Walton et al. 1998). Mutual 
willingness to learn of the operations of the other firm is crucial for partnership development relative to environmental practices (Geffen and Rothenberg 2000). However, dominant firms in the inter-organizational relationship own and control more assets in the chain than subsidiary firms (Cox 2001). Consequently, focal firms should select suitable suppliers to cooperate with in performing green-related practices to ensure long-term success in the global market (Bai and Sarkis 2009; Lee et al. 2009).

This study argues that firm attitudes toward going green and their dominance in supply chains affect their corresponding environmental management practices. Studies on appropriate strategies for supplier relationship management (SRM) vary according to the greening approaches of a firm. Relative power for suppliers remains untapped.

In particular, this research answers the following question:

What supplier environmental management strategy do firms choose as a function of their greening attitude and relationship power dynamics?

The second section of this paper reviews the literature on similar research themes. The third section discusses qualitative research methodologies and case studies conducted in Taiwan in 2013. The fourth section discusses the findings and results obtained from the case study. The fifth section provides framework for future research considerations based on the data analysis results. Finally, the last section offers practical implications, limitations, and suggestions for future research.

\section{Materials and methods}

\section{Supplier relationship management}

\section{Role of the supplier in going green}

According to transaction cost theory (Williamson 1975, 1979), firms manage inter-organizational relationships to minimize cost. Many scholars have indicated that collaborative buyer-supplier relationships are essential to successful business operations (Lee 2009; Quinn et al. 1990; Wagner and Johnson 2004). Focal firms can cope with environment uncertainty in mix, volume, and lead time by employing buyer-focused operations in the supply chain (van der Vaart and van Donk 2004). Focal firms also benefit from collaborating with appropriate and qualified suppliers in terms of operational cost, quality, flexibility, and technological advancement (Gupta and Zhender 1994; Krause et al. 2000). Consequently, business margins are increased, which is the aim of most profit-oriented organizations.

Studies on green supply chain management (green SCM) suggest that collaborative dialog with suppliers helps focal firms to realize the environmental impact of their supply chains (Lamming and Hampson 1996). Researchers (Klassen and Vachon 2003; Rao and Holt 2005) argue that collaborative customer-supplier relationships produce positive environmental outcomes for chain members. Although Lee et al. (2009) highlighted that considering the environmental responsibility of suppliers has complicated the purchasing process of focal firms, suppliers are still critical to the success of firms in going green.

\section{Supplier selection when going green}

Various approaches have been proposed to evaluate and select suppliers. Noci designed "a conceptual approach that first identifies measures for assessing a supplier's environmental performance" in 1997 and suggested "effective techniques for developing the supplier selection procedure according to an environmental viewpoint" (Noci 1997, p.103). This research identifies four environmental categories: green competencies, current environmental efficiency, green image of suppliers, and net life-cycle cost. Forman and Jørgensen (2004) argued that customer-supplier relationships directly affect the environmental strategies firms should choose. If long-term relationships are mainly based on control, then "asymmetrical partnership" is appropriate. In contrast, "symmetrical partnership" is best for firms that build long-term relationships and mutual partnerships with suppliers. Viewpoints vary on how environment-related concerns affect supplier selection. A study in Brazil reveals that firms do not adopt environmental requirements uniformly (Jabbour and Jabbour 2009). However, a group of researchers argues a different perspective. They claim that environment-related concerns affect supplier selection criteria in terms of quality and quantity (Govindan et al. 2013). Bai and Sarkis (2009) recently included supplier sustainability attributes into supplier selection approaches such as pollution production, control and prevention, environmental management system, resource consumption, and employment practices. Various models (Enarsson 1998; Lee et al. 2009) have also been proposed to assist manufacturers in determining the capabilities of a green supplier and to evaluate supplier performance. These studies offer two important messages: They highlight that focal firms going green should cooperate with chain partners instead of being isolated from the chain. They also indicate that greening a supply chain requires classification and differentiation of suppliers (Bai and Sarkis 2014; Zhu et al. 2010).

\section{Supplier improvement and management approaches}

After selecting appropriate suppliers, buying firms should ensure that suppliers can attain common goals with the 
firm. Krause (Krause et al. 1998, 2000; Krause and Scannell 2002) suggested various approaches to supplier development strategies. These approaches include competitive pressure, supplier assessment, supplier incentives, direct involvement in supplier training and education, and temporarily dedicating personnel to suppliers. Thus, "collaboration" is the most advanced form of buyer-supplier relationship (Theodorakioglou et al. 2006).

Theodorakioglou et al. (2006) proposed a set of variables to measure inter-organizational partnership in a supply chain. These variables are supplier policy, information sharing/communication, joint action of supplier/ buyer, relationship-handling issues, supplier support, and relationship quality. Supplier policy considers buy-or-make decisions and establishing long-term relationships with suppliers. Buyer organizations should reduce the number of suppliers and develop formal supplier performance evaluation systems to build strategic partnerships. Information sharing/communication concerns information openness between partners and is essential to the success of the supply chain (Spekman et al. 1998). Joint action of supplier/buyer focuses on supplier and buyer cooperation in solving problems. Relationship-handling issues focus on systematic and formal contact between partners. If buyer organizations are kept well informed of supplier plans and problems, then close relationships are formed between buyers and suppliers (Tan et al. 1999). Supplier support considers supplier development activities. Relationship quality concerns the level of commitment, trust, and cooperation between chain members. These characteristics are not only fundamental to supporting joint actions of supply chain partners (Cheng et al. 2008; Handfield and Bechtel 2002), but also determine the ultimate success or failure of the partnership (Monczka et al. 1995).

Theodorakioglou et al. (2006) supported the positive relationship between the six supplier management approaches and the supply chain activity of quality management. Numerous researchers (Das 2011; Foster and Ogden 2008; Lin et al. 2010; Roloff and Ablander 2010) also consider the framework as appropriate to describe the characteristics of collaborative inter-organizational relationships. These researchers agree that implementing these approaches efficiently improves coping with suppliers and achieving superior supply chain performance.

\section{Relative power}

Power in a buyer-supplier relationship closely relates to the interdependence of the involved entities. Caniëls and Gelderman (2007) suggested that dependence is mutual. The power of an organization over another relies on the net dependence between the two. If company A depends more on company B than company B depends on company A, then company $\mathrm{B}$ has greater power than company A (Pfeffer 1981).

Although collaborative buyer-supplier relationships are beneficial to improve supply chain performance, the relationship is often achieved through an inequitable balance of power (Casciaro and Piskorski 2005; Gulati and Sytch 2007). Channel leaders influence the strategies of other channel members and control various channel operations (Green et al. 1996). Consequently, scholars have always focused on classifying and differentiating suppliers to investigate the appropriateness of managing suppliers in different approaches (e.g., Caniëls and Gelderman 2007; Cox 2001; Dubois and Pedersen 2002; Hallikas et al. 2005). This condition also applies to green SCM. Forman and Jørgensen's (2004) and Zhu et al. (2010) considered different strategies for supplier conditions, whereas they agreed that relative power to suppliers is important.

Numerous methods have been proposed to measure dependence/relative power between trading partners. Resource dependence theory perspective (Pfeffer and Salancik 1978) determines the degree of perceived dependence between buyers and suppliers using three factors: how important the resource is, to what extent the group has discretion over the resource, and to what extent there are limited alternatives; this viewpoint was applied by later researchers (Handfield and Bechtel 2002; Rinehart et al. 2004). These researchers measured dependence by the number of suppliers in the market. If a local market only has a few suppliers for a critical commodity or a single supplier monopolizes the market, then buyer dependence is highly relative to the supplier. Thus, the supplier is more powerful than the buyer in this relationship. Size differences between trading partners also contribute to power asymmetry (Spekman 1988).

Cox (2001) explored buyer and supplier dominance by examining whether buyers can obtain sufficient information and resources to leverage their selected suppliers successfully. Dependence is specifically measured from the magnitude and concentration of exchange, degree of replaceability of the incumbent partner, and magnitude of transaction-specific investments (Gulati and Sytch 2007). Caniëls and Gelderman (2007) summarized difference measures of relative power in the literature and argued that dependence has the following key characteristics: financial magnitude of exchanged resources, criticality of resources, availability of alternative sources, and switching costs incurred when replacing trading partners. Zhu et al. (2010) quantified these variables and provided a model to classify suppliers accordingly. These theoretical and empirical studies support the important role of relative power in classifying suppliers for managerial approaches. 


\section{Greening approach}

Green SCM includes green purchasing, manufacturing, and distribution and reverse logistics (Hervani et al. 2005). Green SCM is discussed from the perspective of greenoriented plan, source, make, deliver, and return in light of the extensive acceptance of SCOR (The Supply Chain Council 2011; Liao 2007; Nikbakhsh 2009). Firms choose one or more practices in their pursuit of green, but the effort they spend and approach they apply vary. Thus, attitude of the leading organization affects chain members because the dominant organization in the buyer-supplier relationship controls chain operations and affects the policies of the subsidiary organization (Green et al. 1996).

In 1993, Kopicki et al. introduced three different attitudes that organizations can take when going green: reactive, proactive, and value seeking. In the reactive approach, companies comply with environmental legislation and commit minimal resources to environmental management. Value seeking is the most far-reaching approach, which incorporates environmental concerns into business strategies to create competitive advantage. Walton et al. (1998) extended the work of Kopicki et al. (1993) and proposed that firms could adopt one to six possible strategies when managing environmental issues. These possible strategies, from reluctant to aggressive, include resistant adaptation, embracing without innovation, reactive, receptive, constructive, and proactive. Firms that are reluctant to adopt environmental-friendly supply chain practices focus on minimizing exposure. Alternatively, firms aim to create a new vision by integrating proactive customers and suppliers into the environmental management process. Klassen (2001) explored how managers react to environmental issues from the plant level and classified reactions to reactive and proactive types according to manager emphasis on short-term or long-term economic value. From the perspective of innovation, Chen et al. (2012) grouped the going green approaches of firms into proactive and reactive types. Reactive types are generated from both internal and external motivations, whereas proactive types are mainly generated from internal motivations (Chen et al. 2012). Although researchers refer to these development phases in different terms [i.e., the "proactive" phase in the work of Walton et al. (1998) is mapping to the "valueseeking" approach in the work of Kopicki et al. (1993)], they agree that organizations only thrive in the final phase when they take the chain as a whole system and integrate customers and suppliers into management activities.

\section{Methods}

This study employed the case study method to collect qualitative data. Case study method explains, describes, illustrates, explores, and evaluates the concepts or phenomena covered in the research questions (Rubin and Babbie 2007; Scapens 1990; Yin 2003). Several high-tech industry firms in Taiwan were selected as target cases to answer the research question of this study. We chose 11 cases because we believe it is an appropriate number for a case study. Case studies with too few cases (less than two to four) produce overly subjective results, whereas too many cases (more than 12-15) produce excessively dispersed results (Perry 1998).

Green issues have been extensively discussed in various industries including high-tech (Lee et al. 2009), automobile (Zhu et al. 2007), package printing (Vachon and Klassen 2006), furniture (Michelsen 2007), electronics (Ninlawan et al. 2010), retail (Bernon et al. 2011), and logistic industries (Jumadi and Zailani 2010; Stank et al. 1996). The case study targeted high-tech companies in Taiwan. Taiwan is the largest manufacturer of computer-related products in the world; Taiwan provides approximately $26 \%$ of the global supply of desktop computers, over $60 \%$ of notebooks, over $90 \%$ of motherboards (Chow et al. 2008; Koh et al. 2011), and over $40 \%$ of the global supply of TFT-LCDs (Lee et al. 2009). IC output value of Taiwan accounts for nearly a quarter of the global output (Hsu and $\mathrm{Hu}$ 2008). These figures illustrate the critical position of high-tech industries in Taiwan in global electronic supply chains. Export is critical to the high-tech economy of Taiwan (Government Information Office 2014); therefore, complying to the regulations in export areas (e.g., Europe and America) is inevitable for industry manufacturers. Consequently, Taiwanese high-tech manufacturers cannot escape green supply chains under rising global environmental awareness.

We collected data to represent various participants in the supply chain and selected two component suppliers, five original design/equipment manufacturers (ODM/OEM), and four brand companies to represent the upstream, midstream, and downstream of the supply chain. The study results are only applicable to this industry.

Interview methodology was utilized to collect data regarding firm attitude and execution to be green. The research directly clarified secondhand information collected from various approaches with people in charge in the corresponding company. Table 1 lists the interviewees who participated in this study. Medium-to-high level managers were chosen as respondents because they were involved in the decision-making process of green-related practices. Respondents also had to be familiar with supplier management, so they can provide insights on the strategy of the company when going greening. Thus, we interviewed 25 interviewees (Table 1); twelve were in the (associate) VP/ director level, while ten were in the (senior) manager level. At least two persons from each company in the case study 
Table 1 Background information of case companies and interviewees

\begin{tabular}{lllll}
\hline $\begin{array}{l}\text { Case } \\
\text { company }\end{array}$ & $\begin{array}{l}\text { Nature of } \\
\text { company }\end{array}$ & $\begin{array}{l}\text { Turnover 2012 } \\
\text { (USD: millions) }\end{array}$ & $\begin{array}{l}\text { Employee number } \\
\text { (globally/Taiwan) }\end{array}$ & Titles of interviewees \\
\hline A & Brand company & 10,176 & $10,318 / 4,283$ & Chief quality officer, senior quality manager \\
B & Brand company & 15,208 & $43,000 / 19,416$ & Director, senior manager \\
C & ODM & 18,213 & $77,679 / 4,505$ & Associate VP, procure manager \\
D & OEM & 36,507 & $70,000 / 5,138$ & Associate VP, \\
E & Brand company & 605 & $1,500+/ 1,454$ & Associate VP, associate director, senior manager \\
F & Component supplier & 765 & (N/A)/1762 & Associate VP, senior manager \\
G & Brand company & 1,691 & $7,070 / 2585$ & Deputy division director, senior manager \\
H & ODM/OEM & 18,765 & $47,977 / 5,140$ & Senior project director, procurement director \\
I & OEM & 956 & (N/A)/8,200 & Director, deputy manager \\
J & Component supplier & 821 & (N/A)/725 & Associate VP, senior marketing and R\&D managers \\
K & OEM & 1,992 & (N/A)/4,231 & Senior quality manager, engineer, manager, senior specialist \\
\hline
\end{tabular}

were interviewed to represent accurately the viewpoint of a firm on the research themes.

Personal interviews were conducted for each company that lasted approximately $1.5-1.75 \mathrm{~h}$. Participants include researchers, managers, and individuals relevant to implementing green practices promoted by the manager. Interviews were semi-structured and followed an interview protocol ("Appendix 1"). According to Yin (2003), interview protocols assist the investigator in targeting the subject under study and force the investigator to anticipate potential problems during the interview. Interviewers asked respondents open questions, so they could easily express their thoughts and insights and provide valuable information. Interviews were recorded, with the knowledge and agreement of the respondent, and then transcribed. Transcripts were organized and returned to the respondents for content validation. If the answers were unclear or required clarification, then the researchers contacted the interviewees by e-mail or phone to conduct another short interview. The researchers also collected secondary data from each case for analysis, including archival data, Web sites, media reports, and corporate social responsibility reports. These data were inspected, defined, and discussed by the research team to double verify interviewee opinions (Yin 2003). The research group examined the correlation among research themes and reasonableness by integrating the data into each case. The research group then discussed and analyzed each case. The case analysis results were modified numerous times until all members of the research team were in agreement.

The three themes investigated in this study were relative power to suppliers, greening approach, and supplier management strategy of buyer organizations. Most companies have multiple suppliers in the real business world, so, for relative power to suppliers, we asked informants to think of one supplier to provide key components and use this supplier to answer the designed questions. The suggestion of researchers (Benton and Maloni 2005; Grant 1997; Hardy 1996) that power is multidimensional and should not be measured through single measurements was followed. The framework of Caniëls and Gelderman (2007) was used in this study to evaluate this power. The four perspectives used were financial magnitude of exchanged resources, criticality of resources, availability of alternative sources, and switching costs when replacing suppliers. This work identified dependence of buyers on suppliers through interviews ("Appendix 2"). If buyer organizations depended heavily on suppliers, then the power ratio of buyer/ supplier was greater than one $(>1)$. Conversely, if suppliers had more bargaining power than buyer organizations, then the power ratio was less than one $(<1)$.

The second theme investigated is the greening approach. This study utilizes multiple factors to determine the greening approach of firms. Kopicki et al. (1993) and van Hoek (1999) stated that firm operations vary according to approaches taken toward greening. The present study adopts this viewpoint and compares the resources that case companies have committed to greening, organizational unit designed and practices implemented for greening, and environment-related audit and award pursued. The greening approach of case companies was explored through interviews. Interview questions were designed to determine how companies implemented greening and their future plans. If case companies comply with regulations and invest minimum resources to the green commitment, then they are taking the reactive approach. In contrast, if they pursue regulations and fulfill customer requests, then they are taking the proactive approach ("Appendix 2").

The last theme investigated is supplier management strategy. This study designed interview questions, 
employing the study of Theodorakioglou et al. (2006) as framework, and considered the supplier management strategy of each case company from six perspectives. The interviews distinguished the importance of the six supplier management practices to each case company and identified whether the case companies emphasize each of these practices (see “Appendix 2").

\section{Results and discussion}

\section{Relative power to suppliers}

Based on the criteria, buyer/supplier power ratio for each case company is either greater $(>)$ or less $(<)$ than one. The first group (Companies A, B, C, D, E, and F) consists of more dominant companies in the inter-organizational relationship (i.e., power ratio of buyer/supplier is greater than one), while the other group (Companies G, H, I, J, and $\mathrm{K}$ ) consists of less dominant companies (i.e., power ratio of buyer/supplier is less than one) ("Appendix 2").

Case study results indicate that business turnovers are key to dominance in an inter-organizational relationship. Thus, we compared the turnover of case companies with that of chosen suppliers as target suppliers in the interview ("Appendix 1"). The results showed that case companies in the first group (buyer/supplier power ratio $>1$ ) typically have substantially higher turnover than their suppliers (i.e., two to three times higher on average according to the financial reports). Case companies in the second group (buyer/supplier power ratio $<1$ ) have no significant difference or have less turnover than their suppliers. The interviews also confirm this finding: "We are a big client. If you want to do business with us, you must listen to us. That's the rule. (Company A)." Thus, some case companies (e.g., Companies A and C) have the right to specify product specifications and quality standards for their suppliers. Conversely, Company H revealed that, "Our (order) volume is not very big to them. When its (supplier) capacity is not sufficient, they first fulfill other big customers who contribute more to their turnover. We are not their priority customers."

Scarcity and criticality of resources are the key when case companies dominate the relationship; this condition echoes the resource dependence theory perspective (Pfeffer and Salancik 1978). No monopoly exists for material and component suppliers in Taiwan because the country has a mature high-tech industry. Therefore, case companies in the first group (buyer/supplier power ratio $>1$ ) always keep a list of multiple suppliers to identify alternative suppliers easily. Suppliers are less dominant in the relationship; thus, they can highly adapt to case companies because they do not want to lose these big accounts. Consequently, suppliers are willing to adapt their resource allocation and product design to meet the particular needs of case companies.

In contrast, suppliers in the second group (buyer/supplier power ratio $>1$ ) typically have advanced knowledge in domain technology. Consequently, buyer organizations do not have significant business advantages. Buyers rely on suppliers in terms of manufacturing technology and process control. "They do not count on us. They are big, and they know what they are doing. Most of the time we need their help. (Company J)." A few suppliers always control the market, which enhances their bargaining power. However, buyer organizations have limited negotiation power. "That's realistic. They are rare in the market. They are the boss. (Company G)."

\section{Greening approach}

In the interviews, seven (Companies A, B, C, D, E, G, and $\mathrm{H})$ of the 11 case companies consider themselves as proactive toward going green, while the other four (Companies $\mathrm{F}, \mathrm{I}, \mathrm{J}$, and $\mathrm{K}$ ) consider themselves as reactive ("Appendix 2 "). The proactive group actively and globally collects environment-related regulations and highly intends on understanding customer needs. Green activities (e.g., redesigning products for improved energy-saving capabilities, selecting recyclable materials for packages, and establishing a new organizational unit for green-related matters) in these companies are supported from top managers to floor staff. The proactive group sets relevant rules that are even stricter than the formal regulations and use them as criteria in choosing supplier partners. In contrast, the reactive group (Companies F, I, J, and K) takes a conservative approach to green practices. Although they understand the importance of going green, they spend relatively little effort because of various reasons. "After all, greening is costly. (Company B)." Consequently, these companies mainly follow the minimum requirement defined by official regulations and what their customers request from them. Their green investments lag behind the development of green-related industry regulations.

We checked the environment-related practices of the case companies in the past 6 years (2007-2013) through secondhand data of media reports and company archival data. We took the SCOR model (The Supply Chain Council 2011) as framework and divided environment-related practices into four types: green design, purchase, manufacture, and logistics. These types correspond to the four fundamental processes of the supply chain (i.e., plan, source, make, and deliver) and provide a comprehensive picture of green-related practices. Some cases have modified their organizational structure to accommodate green practices. Thus, we also determined whether or not the firms have established dedicated units for planning and 
executing green practices (i.e., internal environmental management) from an organizational perspective. "Appendix 3" shows the environment-related practices implemented by each case company. This research also determined whether the case companies are certified or have won any of the 11 environment-related audits and awards. These audits and awards were selected because they are globally well known, highly recognized in Taiwan, and widely respected in the industry. "Appendix 4" shows the results. All seven companies in the reactive group implemented at least three of the five greening practices implemented in the past 6 years, while the other four implemented only one or two. The proactive group has at least five of the 11 environment-related awards/certificates, while the reactive group receives at most three (Companies I and $\mathrm{K}$ ).

\section{Supplier management strategy}

Basing on the classifications of relative power and greening approach, firms are categorized into four different groups: (A) power ratio (buyer/supplier) greater than one and proactive greening approach, (B) power ratio greater than one and reactive greening approach, $(\mathrm{C})$ power ratio less than one and proactive greening approach, and (D) power ratio less than one and reactive greening approach. Subsequently, supplier management approaches of each group are explored (Table 2). This study utilized the framework of Theodorakioglou et al. (2006) for the supplier management approaches. Supplier management approaches are investigated from six different perspectives: supplier policy, information sharing/communication, joint action of supplier/buyer, relationship-handling issues, supplier support, and relationship quality.

Group I consists of five case companies (Companies A, $\mathrm{B}, \mathrm{C}, \mathrm{D}$, and $\mathrm{E}$ ). This group is proactive toward going green and is dominant in inter-organizational relationships. These companies often ask and even force their suppliers to support their activities. They are aggressive in collaborating with suppliers utilizing multiple approaches. They arrange formal and informal meetings for suppliers to assist them in understanding regulations. They also have sufficient resources in establishing channels to communicate and co-work with suppliers, including Web sites and product inspection laboratories. These companies can also provide consultancy and training services when necessary. They invite suppliers to join their product design process, which is a typical activity of "joint action of supplier/ buyer." Considering Companies B and $\mathrm{C}$ as examples, these two companies are characterized as ODMs. They collaborate with suppliers to design products. Consequently, suppliers can produce what these companies like and can outperform their competitors. This group nurtures long-term relationships with suppliers, which, in turn, benefits both parties in green activities. "We have been friends for long, it's the 'trust' that connects us (Company C)."

Group II (Company F) focuses on information sharing/ communication and relationship-handling issues. This company is dominant but is not proactive in going green, and the effort they expend on suppliers is limited. This group does not view suppliers as important to achieving greening objectives. "At this stage, we do not think going green is our priority. Thus, we do not care if our suppliers want to do it (Company F)." This group mainly focuses on establishing a platform to exchange information. Suppliers receive its requirements and can provide material assurance through the system. Company $F$ positions itself as the bridge role, which transfers green-related regulations from international unions to its suppliers. Its dominance forces suppliers to check and obey green-related regulations. Its inter-organizational relationship with its suppliers is transaction-oriented (Oliva and Kallenberg 2003). "Trust" is extremely limited, or even nonexistent, between these partners. Therefore, Company F may conduct business with competitors of its suppliers. "After all, what we care most is who can give us the most benefits in this deal...and only this deal. They (suppliers) understand the rule (Company F)."

Group III (Companies G and H) consider "trust" with suppliers as important to achieve greening objectives. Case study results indicate that this group is proactive in going green that they are happy to exchange information with suppliers and accept supplier improvement suggestions. However, they are less dominant and need to cooperate closely with suppliers. They search for suppliers with the same proactive attitude and ally with them for superior greening performance, which results in a partnership relationship between case companies and suppliers. Although they are not dominant, they still establish long-term relationships with suppliers who have goals of being green. This goal congruence allows them to trust each other and be aware of the needs of the other. Consequently, case companies develop evaluation systems for supplier performance. In these systems, green-related indicators are uniformly listed as supplier selection criteria. These indicators include the use of environmental materials (Companies $\mathrm{G}$ and $\mathrm{H}$ ), capacity to reduce pollution (Companies $\mathrm{G}$ and $\mathrm{H}$ ), capacity to manage reverse flows (Company $\mathrm{G}$ ), and continuous environmental improvement (Company $\mathrm{H}$ ). These indicators are qualitative. "At this stage, we do not think suppliers are able to show their (green) abilities in numbers. If we really need them (to) do that, we need to help (Company G)."

Group IV companies (Companies I, J, and K) take limited action in coping with their suppliers in achieving 


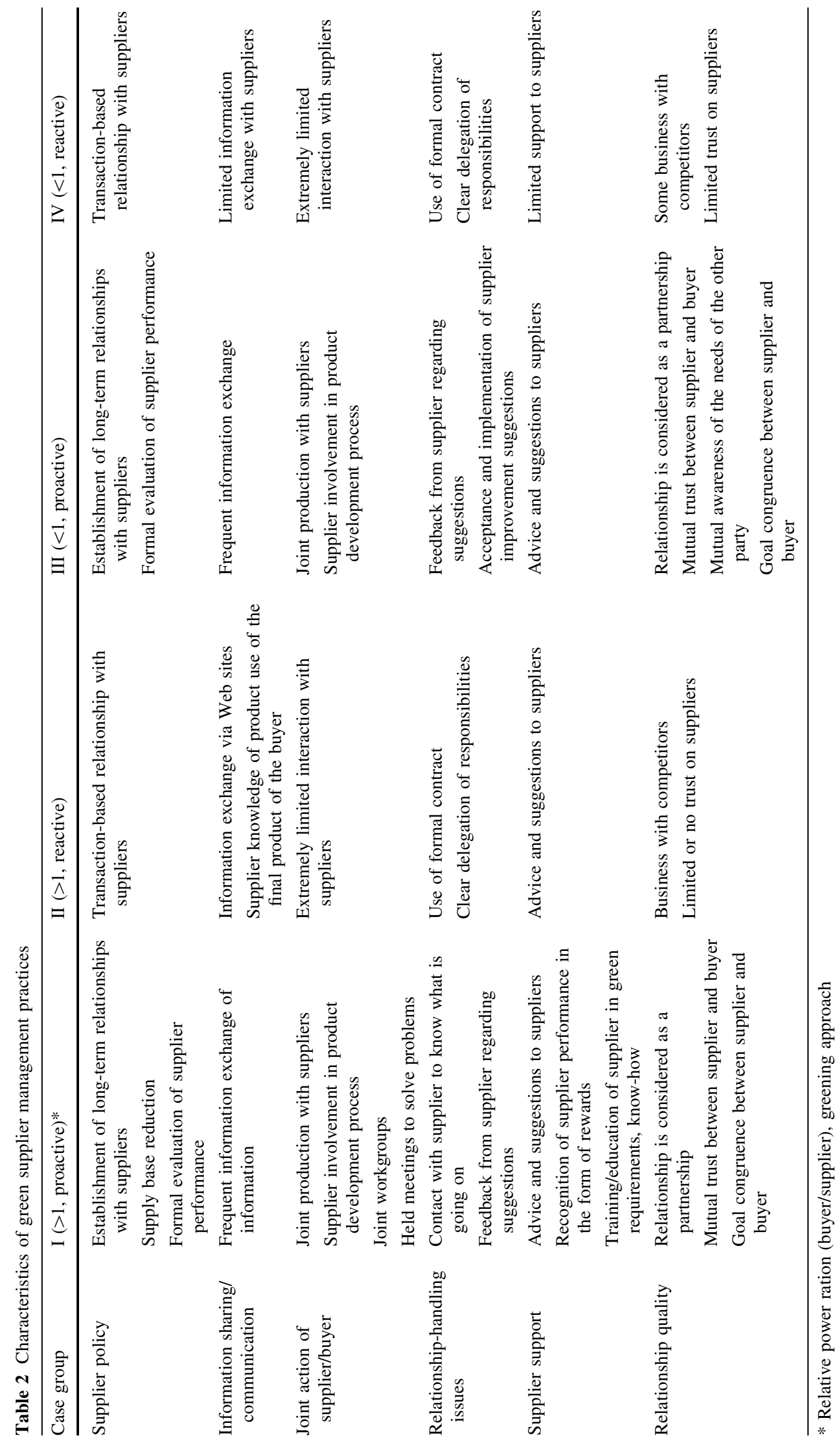


greening objectives. Given that these companies are reactive and are nondominant in their relationship with suppliers, these companies are only concerned whether their suppliers meet the minimum requirements of customers. In most cases, their suppliers are aware of this because the high-tech industry has been mature in Taiwan (according to Company I). Given that these companies appear to be relatively small, they generally do not have power over their suppliers. Similar to Group II, their relationship with their suppliers appears to be built mainly on formal contracts. The responsibilities of both parties are clearly delegated in the contract for each single transaction. The companies react to the feedback and suggestions of their suppliers only when they realize that these changes are required to survive in the market. "We are not big. Our resources are limited. We do it (green) only when it is needed." (Company K).

The aforementioned findings can be explained by theory of stakeholder management (Freeman 1984). As stated (Co and Barro 2009), organizations should adopt different approaches in dealing with various stakeholder groups in supply chains. Although numerous strategies are proposed (e.g., Bunn et al. 2002; Polonsky and Ottman 1998; Savage et al. 1991), most firms actually attempt to obtain a balance between two basic influence strategies, namely coercion and compromise (Frooman 2005). These two basic influence strategies are also discussed in this research. Notably, dominant companies are more likely to adopt aggressive strategies in managing their suppliers. However, rather than taking the "coercion" strategy, most companies are "cooperating" with their suppliers. Examples are those companies of Groups I and II. Whether they are aggressive in being green, they take cooperative approaches with suppliers, such as constant advice and suggestions. We suppose that this cooperative approach is due to the nature of today's business world wherein customer-supplier relationships are often complex. In a dyadic relationship, one company could be the supplier and customer of the other company simultaneously. As a consequence, using threats or orders to force another company to take a particular action is not easy for a certain company. In terms of the companies of Groups III and IV, although they take a more "compromising" strategy because of their less dominant position in the relationship, these companies can still be involved in the operations process of buyer organizations and jointly contribute to production decisions. This finding further reflects the fact that, in the pursuit of being green, firms should not be isolated from the supply chain, resulting in close linkage with suppliers, which, in turn, drives the focus of the buyer organization to a specific party among numerous stakeholders. As such, both parties are able to cowork for the improvement of environmental performance.
A framework for future research consideration

Based on the case study results, this study named the four strategies adopted by Groups A, B, C, and D as strategic alliance, arm's length relationship, partnership, and ongoing relationship, respectively (shown in Table 3).

The "strategic alliance" strategy represents the longterm relationship between the buyer and supplier organizations. This strategy entails multifunctional interaction between the buyer and supplier organizations, such as marketing, production planning, and quality management (Pyke and Johnson 2004). Given that Group I companies are big accounts to their suppliers, who do not want to lose these accounts, these companies can request and even force their suppliers to join their greening practices. Suppliers aiming to achieve higher greening performance can also attract more customer trust. The resulting mutual trust, in turn, drives the full share of information and joint actions in achieving a mutual common goal (Cheng et al. 2008; Spekman et al. 1998). Buyer organizations are also willing to reduce the number of suppliers. By doing so, the partnership relationship becomes closer and leads to deeper involvement of the suppliers in the business processes of the buyers. Supplier performance is formally evaluated for further reference.

The "arm's length relationship" strategy is for Group II. This strategy enables buyer organizations to handle their suppliers on a onetime purchase basis, without commitment to each other. Similar to the statement of Company F, "We choose suppliers from the bidding market. If you can provide us the material with the lowest price, you get the deal-but only this time." Consequently, the buyer organization adopting this strategy manages suppliers at arm's length only. Although they also share information with suppliers, the information is limited to onetime business. The formal contract is utilized to delegate clearly the responsibilities of each party. As a result of the arm's length relationship, trust between these parties is limited, although it can be considered beneficial to buyer organizations more than suppliers. Thus, we propose this strategy as appropriate for companies who are in the leading

Table 3 Green supplier management strategy matrix

\begin{tabular}{lll}
\hline $\begin{array}{l}\text { Power ratio } \\
\text { (buyer/supplier) }\end{array}$ & Greening approach & \\
\cline { 2 - 3 } & Proactive & Reactive \\
\hline$>1$ & $\begin{array}{c}\text { Strategic alliance } \\
\text { (Group I) }\end{array}$ & $\begin{array}{c}\text { Arm's length relationship } \\
\text { (Group II) }\end{array}$ \\
& $\begin{array}{c}\text { Partnership } \\
\text { (Group III) }\end{array}$ & $\begin{array}{c}\text { Ongoing relationship } \\
\text { (Group IV) }\end{array}$ \\
\hline
\end{tabular}


position of the dyadic relationship but are reluctant to invest in going green.

In the third strategy, "partnership," buyer organizations share some information with partners and trust some partners. Given that buyer organizations have high intentions in improving their environment-related performance, but do not have relationship dominance, they are pleased to adjust their business processes to cooperate with their suppliers. The buyer organizations select suppliers who they intend to transit "from being an important supplier to becoming a supply chain partner" (Spekman et al. 1998, p. 56). If their suppliers are also proactive toward going green, then both parties can easily establish mutual awareness of the needs of the other and achieve goal congruence, thus generating a "partnership" relationship. Both parties attempt to maintain this relationship over an extended time period.

Finally, the "ongoing relationship" represents a strategy used by buyer organizations reluctant to invest in greening and less dominant in the relationship with their suppliers. With this strategy, buyer organizations rely on their suppliers for improvement. The buyer organizations do not pursue close relationships with suppliers. The buyer organizations follow relevant regulations at the request/suggestion of their suppliers to build an "ongoing relationship." Compared with the "arm's length relationship" strategy based on the "onetime purchase" business, firms with this "ongoing relationship" attempt to build longer-term relationships with suppliers but are still transaction-based. However, if required, then these firms will also do business with the competitors of their suppliers. Information sharing is insufficient, and trust between partners is still limited.

\section{Conclusion}

Although the data presented in this study are exploratory in nature, they help us have a clearer understanding of the management of supplier relationships for firms in going green. By classifying focal firms in accordance with the two dimensions of relative power to supplier and the greening approach they take, various supplier management practices are investigated. Specifically, Table 2 provides the empirical observation from 11 case companies, and Table 3 shows the appropriate strategies proposed by this study.

A number of conclusions can be drawn from this study. As indicated by the findings, the power of the buyers relative to the suppliers and the greening approach are indeed essential factors in managing suppliers. Although the literature proposes that power in the dyadic relationship can be examined from multiple perspectives, our findings reveal that business turnover appears to be the most important factor. Firms that have higher turnover own more resources in the market, thus obtaining more power over other partners. Additionally, for most case companies, their greening approach is considered to be "value seeking" because the future development of regulations and the acceptance of end consumers are still uncertain at the current stage. Although some case companies are proactive and preempt new legislation, "it is still a long way to go to take "green" into our business strategy" (Company D). After all, "green" itself is costly, according to Companies $\mathrm{B}$ and $\mathrm{H}$.

Undoubtedly, the collaboration between partners benefits both parties in achieving business goals. This collaboration between partners is not an exception when going green. The firm in the leading position of the dyadic relationship seems to control the major operations. If the dominant firms are proactive in green-related activities, then they search for partners who can support their goal. A well-known example in Taiwan is ASUSTeK Computer Inc (also referred as ASUS), the fifth largest PC vendor in the world by 2013 unit sales and also the first Taiwanese information technology company to participate in the Electronic Product Environmental Assessment Tool (EPEAT). ASUS established its green supply chain to meet the EPEAT criteria. ASUS set up strict selection and audit processes to collaborate with and assist its suppliers. As such, those suppliers are ensured to comply with the quality management and green guidelines of ASUS. ASUS also established annual supplier workshops to communicate policies and other green relevant issues to its suppliers. After such a close working relationship with suppliers in the past few years, ASUS is now well recognized as a hightech company with good environmental performance.

On the other end of the continuum, reactive firms keep their discussion and selection of suppliers on the price basis. The relationship is more adversarial. If the buyer organizations are nondominant in the relationship, then they need to accept different strategies. For those firms that are proactive, they select partners with comparable goals. A proactive attitude will lead a captive buyer to commit minimal resources and to conform to the minimum requirements of legislation.

Overall, our conceptualization has theoretical and practical importance and lays the foundation for future studies concerning the management of supplier relationships when going green. Our conceptualization also provides a guideline for practitioners, by indicating the importance of the dominant power to suppliers when implementing green-related practices. With this understanding in mind, practitioners can determine their position in the matrix and, in turn, develop the appropriate strategy to achieve the green-related objectives. 
The data for this study were collected from a high-tech industry in Taiwan. The sample was relatively small and not representative of Taiwanese industry as a whole. Our ability to generalize the data is limited, particularly in other industries. Thus, we need to be cautious on how we interpret the implications of the results. The collected data were analyzed by the research team, which may involve subjective factors. Furthermore, we examine the SRM from the perspective of the buyers. A dyadic approach would most certainly lead to more insights.

Future scholars may expand on the incomplete areas of this study. Relevant studies may be conducted on different industries and in different areas to generalize our results further. To solve the potential subjective factors of qualitative data analysis, we propose that quantitative data be collected for discussion. Once the relationship of research themes has been established, scholars may further discuss the relationship between supplier management approaches and performance to verify whether coordination among the greening approach, relative power to suppliers, and supplier management practices can improve firm performance when going green.

Acknowledgments This study was supported by the Ministry of Science and Technology, Taiwan R.O.C. (NSC 99-2410-H-004-134).

\section{Appendix 1}

See Table 4.

Table 4 Interview protocol

Before the interview, the researcher explained the research objective, the information intended to be collected, and the explanation of the research concepts to each informant.

The questions are structured as follows:

Part 1: Company background

Please describe your industry section and your business nature.

Please describe your relationship with your suppliers and customers.

Part 2: Greening approach

Please describe to what extent your organization will invest for going green.

Please describe what your organization has done for going green. (Prompt: green design, green purchase, green manufacturing, and green logistics.) Is there any organization redesign for this purpose (internal environment management)?

Please describe how your organization reacts to the regulations related to green.

Please describe if there is any environment-related audit/award important to your organization.

Part 3: Relative power

(The researcher asked the informant take one supplier in mind, which provides the key component, and use this supplier as the target to answer the following questions.)

Please describe how critical this component to your organization. Is it easy to obtain substitutes for this component?

Please name one supplier that provides key components to your company.

Please describe how your organization used to collaborate with this supplier. Who used to take the dominance and how?

Please describe the market of the key component. Is it monopolized by just a few suppliers?

Please describe what you have to do if your organization needs to replace this supplier.

Based on your experience and observation, does your organization rely on this supplier in terms of order or technology?

Part 4: Supplier management strategy

Please describe what supplier policy your company is adopting.

Please describe what information, how, and how often your company communicates and shares with suppliers.

Please describe what actions your company ever works with suppliers jointly, and how.

Please describe the approaches/mechanisms your company uses in managing suppliers.

Please describe to what extent your company supports suppliers, and how.

Based on your observation, how your company and the supplier view the relationship of both parties? 


\section{Appendix 2}

\section{See Table 5 .}

Table 5 Transcription summary of perceived research themes

\begin{tabular}{l}
\hline Cases involved/examples from cases \\
$\begin{array}{l}\text { Power ratio (buyer/supplier) } \\
\text { Greater than one }(>1)\end{array}$ \\
A, B, C, D, E, F \\
A: The supplier management approach applies to all suppliers. If we need you to do this, then you just follow. \\
Otherwise, we break \\
C: Our suppliers try to meet our requests, such as capital, technology, order, and many others \\
D: We have multiple sources for one single item, sometimes two, sometimes even three or four. Our suppliers \\
realize this, so they try hard to be listed in the front \\
G, H, I, J, K \\
G: We are not strong enough. As you know, suppliers also select their customers. We are not strong enough at this \\
moment \\
H: $\ldots$ because we are not their major customers. If they have to select, then they will prioritize other companies \\
higher than us \\
J: Our company size is relatively small in this industry. It is not easy for us to bargain with the supplier
\end{tabular}

Greening approach

Proactive

A, B, C, D, E, G, H

B: ... our green is from cradle to cradle, from design, purchase, manufacturing, marketing, and reverse logistics. That is what we call a complete life cycle

$\mathrm{C}$ : We are demanding with regard to environmental issues. Our suppliers feedback this to us. Compared with other companies, we ask them to do many things for us

G: We are serious with regard to restricted materials. We always check those materials and do report. The number of materials restricted by our company is more than the six materials specified in the RoHS

Reactive $\quad$ F, I, J, K

F: We are reactive. Given that we have customers, we listen to our customers. We only do these things if our customers need us to do so. That is the only reason we do

J: Our companies need to import products to Europe. The European regulations are what we comply with and the only thing we care about

$\mathrm{K}: \ldots$ it (going green) costs. If our customers ask us do so, then we inquire from our partners in the industry. If that is inevitable in the near future, then we do. Otherwise, we like to wait

Supplier management practices

Supplier policy

shariong/ communication

Joint action of supplier/ buyer
$\mathrm{A}, \mathrm{B}, \mathrm{C}, \mathrm{E}$

C: We have set a process to validate that our suppliers met our requirements. Only those who pass the process can obtain our vendor code and be listed in the qualified vendor list

E: ... Green performance is also in our survey form. The survey form is evaluated by the procurement, R\&D, and SRM departments. We monitor and manage our suppliers continuously

A, B, C, D, E, F, G, H, K

D: We have annual supplier meetings. In the meeting, we announce our latest plan and requirements to suppliers. We also use Web sites and e-mail to notify them of any new updates

F: Our procurement persons are responsible for communicating with suppliers about new regulations. Our information center always assist our procurement persons understand the details

A, B, C, E

B: Our suppliers are in partnership with us. We build a team to achieve the goal of sustainability. We set performance indicators for this team and review them twice a year

C: If we have a long-term relationship with our suppliers, then we always co-work with them. Sometimes our engineers stay in our supplier site to assist them in improving the manufacturing processes 
Table 5 continued

Perceived themes
$\begin{aligned} & \text { Relationship-handling } \\ & \text { issues }\end{aligned}$
A, B, C, D, E, F, G, H, I, J, K
E: We are always happy to listen to our suppliers. Sometimes they complain. We listen to them. We are hoping to
develop the appropriate strategy for both parties
G: We have a green procurement system. Via this system, our suppliers can tell us what they can or cannot do. We
will respond
A, B, C, D, E, G, H
A: We provide support to our supplier based on how important they are to us. For this company, we tutor them.
We help them to learn new technology
Bupplier support
discussion. If our suppliers need any help, then we help
G, H
G: We inquire whether this company would be willing to undergo certain adjustments for us. If they do, then this
means that they trust us to some extent. If they not, then, in some cases, we might force them
H: We take the relationship with suppliers seriously because we rely on them for technology, particularly if they
are pioneers in this area and monopolize the market

\section{Appendix 3}

See Table 6.

Table 6 Greening practices implemented by each case company

\begin{tabular}{ll}
\hline Greening practices & Cases involved \\
\hline Green design & $\mathrm{A}, \mathrm{B}, \mathrm{C}, \mathrm{D}, \mathrm{E}, \mathrm{F}, \mathrm{G}, \mathrm{H}, \mathrm{I}, \mathrm{J}, \mathrm{K}$ \\
Green purchase & $\mathrm{A}, \mathrm{B}, \mathrm{C}, \mathrm{D}, \mathrm{E}, \mathrm{G}, \mathrm{H}, \mathrm{K}$ \\
Green manufacture & $\mathrm{A}, \mathrm{B}, \mathrm{D}, \mathrm{H}, \mathrm{J}$ \\
Green logistics & $\mathrm{A}, \mathrm{B}, \mathrm{C}, \mathrm{D}, \mathrm{E}, \mathrm{G}, \mathrm{H}, \mathrm{I}$ \\
Internal environment management & $\mathrm{A}, \mathrm{B}, \mathrm{D}, \mathrm{E}, \mathrm{G}$ \\
\hline
\end{tabular}

\section{Appendix 4}

See Table 7.

Table 7 Perceived environment-related awards/certificates of each case company

\begin{tabular}{ll}
\hline Awards/certificates & Cases involved \\
\hline EPEAT & A $(2013 *)$ C (2012) D (2012) E (2013) H \\
EU flower & A (2010) I (2010) K (2011) C (2012) \\
Energy star & A (2013) B (2010) D (2012) E (2011) G \\
& (2009) H (2010) \\
Eco-label & A (2013) D (2010) \\
\hline
\end{tabular}

Table 7 continued

\begin{tabular}{ll}
\hline Awards/certificates & Cases involved \\
\hline Eco-mark & A (2010) C (2012) D (2012) E (2011) H \\
$\begin{array}{l}\text { Taiwanese green } \\
\text { mark }\end{array}$ & A (2010) C (2012) D (2012) E (2013) G \\
$\begin{array}{l}\text { Taiwanese EPD } \\
\text { label }\end{array}$ & A (2005) H (2010) I (2012) K (2013) B (2007) C (2009) D (2012) \\
$\begin{array}{l}\text { China } \\
\text { environmental } \\
\text { labeling }\end{array}$ & A (2013) B (2010) D (2012) E (2009) H \\
$\begin{array}{l}\text { Carbon footprint } \\
\text { verification }\end{array}$ & A (2013) B (2010) C (2009) G (2010) \\
$\begin{array}{l}\text { If green product } \\
\text { design award }\end{array}$ & A (2013) C (2011) G (2013) \\
$\begin{array}{l}\text { ISO 14001 } \\
\text { All (between 1998 and 2011) }\end{array}$
\end{tabular}

* Year that most recently awarded/certified

\section{References}

Bai C, Sarkis J (2009) Integrating sustainability into supplier selection with grey system and rough set methodologies. Int J Prod Econ 124(1):252-264

Bai C, Sarkis J (2014) Determining and applying sustainable supplier key performance indicators. Supply Chain Manag Int J 19(3): 275-291

Bansal P, Roth K (2000) Why companies go green: a model of ecological responsiveness. Acad Manag J 43(4):717-736 
Benton WC, Maloni M (2005) The influence of power driven buyer/seller relationships on supply chain satisfaction. J Oper Manag 23(1):1-21

Bernon M, Rossi S, Cullen J (2011) Retail reverse logistics: a call and grounding framework for research. Int J Phys Distrib Logist Manag 41(5):484-510

Beske P, Seurig S (2014) Putting sustainability into supply chain management. Supply Chain Manag Int J 19(3):322-331

Bowen FE, Cousins PD, Lamming RC, Faruk AC (2001) The role of supply management capabilities in green supply. Prod Oper Manag 10(2):174-189

Bunn MD, Savage GT, Holloway BB (2002) Stakeholder analysis for multi-sector innovations. J Bus Ind Mark 17(2/3):181-203

Caniëls MCJ, Gelderman CJ (2007) Power and interdependence in buyer supplier relationships: a purchasing portfolio approach. Ind Mark Manage 36(2):219-229

Casciaro T, Piskorski MJ (2005) Power imbalance, mutual dependence, and constraint absorption: a closer look at resource dependence theory. Adm Sci Q 50(2005):167-199

Chen Y-S, Chang C-H, Wu F-S (2012) Origins of green innovations: the differences between proactive and reactive green innovations. Manag Decis 50(3):368-398

Cheng J-H, Yeh C-H, Tu C-W (2008) Trust and knowledge sharing in green supply chains. Supply Chain Manag Int J 13(4): 283-295

Chien MK, Shih LH (2007) An empirical study of the implementation of green supply chain management practices in the electrical and electronic industry and their relation to organizational performances. Int J Environ Sci Technol 4(3):383-394

Chow WS, Madu CN, Kuei C-H, Lu MH, Lin C, Tseng H (2008) Supply chain management in the US and Taiwan: an empirical study. Omega 36(5):665-679

Clarke et al (1994) The challenge of going green. Harv Bus Rev 72(4):37-50

Co HC, Barro F (2009) Stakeholder theory and dynamics in supply chain collaboration. Int J Oper Prod Manag 29(6):591-611

Cox A (2001) Understanding buyer and supplier power: a framework for procurement and supply competence. J Supply Chain Manag $37(2): 8-15$

Das K (2011) A quality integrated strategic level global supply chain model. Int J Prod Res 49(1):5-31

Dubois A, Pedersen A-C (2002) Why relationships do not fit into purchasing portfolio models: a comparison between the portfolio and industrial network approaches. Eur J Purch Supply Manag $8(1): 35-42$

Eltayeb TK, Zailani S (2009) Going green through green supply chain initiatives towards environmental sustainability. Oper Supply Chain Manag 2(2):93-110

Enarsson L (1998) Evaluation of suppliers: how to consider the environment. Int J Phys Distrib Logist Manag 28(1):5-17

Forman M, Jørgensen MS (2004) Organising environmental supply chain management: experience from a sector with frequent product shifts and complex product chains: the case of the Danish textile sector. Greener Manag Int 45(Spring):43-62

Foster ST Jr, Ogden J (2008) On difference in how operations and supply chain managers approach quality management. Int J Prod Res 46(24):6945-6961

Freeman RE (1984) Strategic management: a stakeholder approach. Pitman, Boston

Frooman J (2005) Stakeholder influence strategies: the roles of structural and demographic determinants. Bus Soc 44(1):3-31
Geffen CA, Rothenberg S (2000) Suppliers and environmental innovation: the automotive paint process. Int J Oper Prod Manag 20(2):166-186

Government Information Office (2014) Taiwan yearbook 2013: Economy

Govindan K, Rajendran S, Sarkis J, Murugesan P (2013) Multi criteria decision making approaches for green supplier evaluation and selection: a literature review. J Clean Prod 2013(2013):1-18

Grant RR (1997) Measuring corporate power: assessing the options. J Econ Issues 31(2):453-460

Green K, Morton B, New S (1996) Purchasing and environmental management: interaction, policies and opportunities. Bus Strategy Environ 5(1996):188-197

Green K, Morton B, New S (1998) Green purchasing and supply policies: do they improve companies' environmental performance? Supply Chain Manag 3(2):89-95

Green K, Morton B, New S (2000) Greening organizations. Organ Environ 13(2):206-228

Guide VDR Jr, Van Wassenhove LN (2002) The reverse supply chain. Harv Bus Rev 80(2):25-26

Guide VDR Jr, Muyldermans L, Van Wassenhove LN (2005) Hewlett-Packard company unlocks the value potential from time-sensitive returns. Interfaces 35(4):281-293

Gulati R, Sytch M (2007) Dependence asymmetry and joint dependence in interorganizational relationships: effects of embeddedness on a manufacturer's performance in procurement relationships. Adm Sci Q 52(1):32-69

Gupta MC, Zhender D (1994) Outsourcing and its impact on operations strategy. Prod Inventory Manag J 35(3):70-75

Hallikas J, Puumalainen K, Vesterinen T, Virolainen V-M (2005) Risk-based classification of supplier relationships. J Purch Supply Manag 11(2-3):72-82

Handfield RB, Bechtel C (2002) The role of trust and relationship structure in improving supply chain responsiveness. Ind Mark Manag 31(4):367-382

Hardy C (1996) Understanding power: bringing about strategic change. Br J Manag 7(Special Issue):3-16

Hervani AA, Helms MM, Sarkis J (2005) Performance measurement for green supply chain management. Benchmark Int J 12(4): $330-353$

Hsu C-W, Hu AH (2008) Green supply chain management in the electronic industry. Int J Environ Sci Technol 5(2):205-216

Hu AH, Chen S-H, Hsu C-W, Wang C, Wu CL (2012) Development of sustainability evaluation model for implementing product service systems. Int J Environ Sci Technol 9(2):343-354

Jabbour ABLS, Jabbour CJC (2009) Are supplier selection criteria going green? Case studies of companies in Brazil. Ind Manag Data Syst 109(4):477-495

Jumadi H, Zailani S (2010) Integrating green innovations in logistics services towards logistics services sustainability: a conceptual paper. Environ Res J 4(4):261-271

Klassen RD (2001) Plant-level environmental management orientation: the influence of management views and plant characteristics. Prod Oper Manag 10(3):257-275

Klassen RD, Vachon S (2003) Collaboration and evaluation in the supply chain: the impact on plant-level environmental investment. Prod Oper Manag 12(3):336-352

Koh SCL, Gunasekaran A, Tseng CS (2011) Cross-tier ripple and indirect effects of directives WEEE and RoHS on greening a supply chain. Int J Prod Econ (In Press) 
Kopicki R, Berg MJ, Legg L (1993) Reuse and recycling-reverse logistics opportunities. Council of Logistics Management, Oak Brook

Krause DR, Scannell TV (2002) Supplier development practices: product-and service-based industry comparisons. J Supply Chain Manag 38(2):13-21

Krause DR, Handfield RB, Scannell TV (1998) An empirical investigation of supplier development: reactive and strategic processes. J Oper Manag 17(1):39-58

Krause DR, Scannell TV, Calantone RJ (2000) A structural analysis of the effectiveness of buying firms' strategies to improve supplier performance. Decis Sci 31(1):33-54

Lamming RC, Hampson J (1996) The environment as a supply chain management issue. Br J Manag 7(1):45-62

Lee K-H (2009) Why and how to adopt green management into business organizations? The case study of Korean SMEs in manufacturing industry. Manag Decis 47(4):1101-1121

Lee AHI, Kang H-Y, Chang F, Hung H-C (2009) A green supplier selection model for high-tech industry. Expert Syst Appl 36(4):7917-7927

Liao Y-H (2007) The study and case analysis of green supply chain operations reference model. Ecol Econ 2007(10s):203-207

Lin Y-T, Chang S-C, Yu H-C (2010) The implementation of SCM concepts and information technology to the photomask supply management of IC companies. Int $\mathrm{J}$ Adv Manuf Technol 49(1):227-238

Michelsen O (2007) Investigation of relationships in a supply chain in order to improve environmental performance. Clean Technol Environ Policy 9(2):115-123

Monczka RM, Callahan TJ, Nichols EL Jr (1995) Predictors of relationships among buying and supplying firms. Int $\mathrm{J}$ Phys Distrib Logist Manag 25(10):45-59

Nikbakhsh E (2009) Green supply chain management. In: Farahani RZ, Davarzani H, Asgari N (eds) Supply chain and logistics in national, international and governmental environment. PhysicaVerlag, Wurzburg, pp 195-220

Ninlawan C, Sueksan P, Tossapol K, Pilada W (2010) The implementation of green supply chain management practices in electronics industry. Paper presented at the proceedings of the international multi conference of engineers and computer scientists, Hong Kong

Noci G (1997) Designing 'green' vendor rating systems for the assessment of a supplier's environmental performance. Eur J Purch Supply Manag 3(2):103-114

Oliva R, Kallenberg R (2003) Managing the transition from products to services. Int J Serv Ind Manag 14(2):160-172

Perry C (1998) Processes of a case study methodology for postgraduate research in marketing. Eur J Mark 32(9/ 10):785-802

Pfeffer J (1981) Power in organizations. Pitman Publishing Inc, Massachusetts

Pfeffer J, Salancik GR (1978) The external control of organizations: a resource dependence perspective. Harper \& Row, New York

Polonsky M, Ottman J (1998) Stakeholders contribution to the green new product development process. J Mark Manag 14:533-557

Pyke DF, Johnson ME (2004) Sourcing strategy and supplier relationships: alliances versus e-procurement. Springer, US, pp 77-89

Quinn JB, Doorley TL, Paquette PC (1990) Beyond products: services-based strategy. Harv Bus Rev 68(2):58-67
Rao P, Holt D (2005) Do green supply chains lead to competitiveness and economic performance? Int J Oper Prod Manag 25(9/ 10):898-916

Rinehart LM, Eckert JA, Handfield RB, Page TJ Jr, Atkin T (2004) An assessment of supplier-customer relationships. J Bus Logist 25(1):25-62

Roloff J, Ablander MS (2010) Corporate autonomy and buyersupplier relationships: the case of unsafe Mattel toys. J Bus Ethics 97:517-534

Rubin A, Babbie ER (2007) Essential research methods for social work. Thomson Brooks/Cole, Balmont

Savage GT, Nix TW, Whitehead CJ, Blair JD (1991) Strategies for assessing and managing organizational stakeholders. Executive $5(2): 61$

Scapens RW (1990) Researching management accounting practice: the role of case study methods. Br Account Rev 22(3):259-281

Simpson DF, Power DJ, Samson D (2007) Greening the automotive supply chain: a relationship perspective. Int J Oper Prod Manag 27(1):28-48

Spekman RE (1988) Strategic supplier selection: understanding longterm buyer relationships. Bus Horiz 31(4):75-81

Spekman RE, Kamauff JW Jr, Muhr N (1998) An empirical investigation into supply chain management: a perspective on partnerships. Int J Phys Distrib Logist Manag 28(8):630-650

Stank TP, Daugherty PJ, Ellinger AE (1996) Information exchange, responsiveness and logistics provider performance. Int J Logist Manag 7(2):43-57

Tan K-C, Kannan VR, Handfield RB, Ghosh S (1999) Supply chain management: an empirical study of its impact on performance. Int J Oper Prod Manag 19(10):1034-1052

The Supply Chain Council (2011) SCOR model version 10.0 (http:// www.supply-chain.org/) Retrieved 12, 2011, from http://www. supply-chain.org/

Theodorakioglou Y, Gotzamani K, Tsiolvas G (2006) Supplier management and its relationship to buyer's quality management. Supply Chain Manag Int J 11(2):148-159

Vachon S, Klassen RD (2006) Green project partnership in the supply chain: the case of the package printing industry. J Clean Prod 14(6/7):661-671

van Hoek RI (1999) From reversed logistics to green supply chains. Supply Chain Manag Int J 4(3):129-135

van der Vaart T, van Donk DP (2004) Buyer focus: evaluation of a new concept for supply chain integration. Int $\mathrm{J}$ Prod Econ 92(2004):21-30

Wagner SM, Johnson JL (2004) Configuring and managing strategic supplier portfolios. Ind Mark Manag 33(8):717-730

Walley N, Whitehead B (1994) It's not easy being green. Harv Bus Rev 72(3):46-52

Walton SV, Handfield RB, Melnyk SA (1998) The green supply chain: integrating suppliers into environmental management processes. Int J Purch Mater Manag 34(2):2-11

Williamson OE (1975) Markets and hierarchies, analysis and antitrust implications: a study in the economics of internal organization. Free Press, New York

Williamson OE (1979) Transaction-cost economics: the governance of contractual relations. J Law Econ 22(2):233-261

Yin RK (2003) Case study research: design and methods. Sage Publications, Thousand Oaks

Zhu Q, Sarkis J (2004) Relationships between operational practices and performance among early adopters of green supply chain 
management practices in Chinese manufacturing enterprises. J Oper Manag 22(3):265-289

Zhu Q, Sarkis J, Lai K-H (2007) Green supply chain management: pressures, practices and performance within the Chinese automobile industry. J Clean Prod 15(11-12):1041-1052
Zhu Q, Dou Y, Sarkis J (2010) A portfolio-based analysis for green supplier management using the analytical network process. Supply Chain Manag Int J 15(4):306-319 